\title{
Novel copper(II) complexes with hydrazides and heterocyclic bases: Synthesis, structure and biological studies
}

\author{
Drielly A. Paixão ${ }^{\mathrm{a}}$, Ivana M. Marzano ${ }^{\mathrm{b}}$, Edgar H.L. Jaimes ${ }^{\mathrm{b}}$, Marcos Pivatto ${ }^{\mathrm{a}}$, Débora L. Campos ${ }^{\mathrm{c}}$, \\ Fernando R. Pavan ${ }^{\mathrm{c}}$, Victor M. Deflon ${ }^{\mathrm{d}}$, Pedro Ivo da S. Maia ${ }^{\mathrm{e}}$, Ana M. Da Costa Ferreira ${ }^{\mathrm{f}}$, \\ Isadora A. Uehara ${ }^{g}$, Marcelo J.B. Silva ${ }^{g}$, Françoise V. Botelho ${ }^{\text {, }}$, Elene C. Pereira-Maia ${ }^{\mathrm{b}}$, \\ Silvana Guilardi ${ }^{\mathrm{a}}$, Wendell Guerra ${ }^{\mathrm{a}, *}$ \\ a Instituto de Química, Universidade Federal de Uberlândia, Uberlândia, MG, Brazil \\ b Departamento de Química, Universidade Federal de Minas Gerais, Belo Horizonte, MG, Brazil \\ ${ }^{\mathrm{c}}$ Faculdade de Ciências Farmacêuticas, UNESP - Universidade Estadual Paulista, Campus Araraquara, 14.800-903 Araraquara, SP, Brazil \\ d Instituto de Química de São Carlos, Universidade de São Paulo, São Carlos, SP, Brazil \\ e Instituto de Ciências Naturais, Exatas e Educação, Universidade Federal do Triângulo Mineiro, Uberaba, MG, Brazil \\ ${ }^{\mathrm{f}}$ Instituto de Química, Universidade de São Paulo, São Paulo, SP, Brazil \\ ${ }^{\mathrm{g}}$ Instituto de Ciências Biomédicas, Universidade Federal de Uberlândia, Uberlândia, MG, Brazil \\ ${ }^{\mathrm{h}}$ Instituto de Genética e Bioquímica, Universidade Federal de Uberlândia, Uberlândia, MG, Brazil
}

\section{A R T I C L E I N F O}

\section{Keywords:}

Copper(II) complexes

Hydrazide

DNA binding

Apoptosis

Antitumoral activity

Mycobacterium tuberculosis

\begin{abstract}
A B S T R A C T
Five new copper(II) complexes of the type $\left[\mathrm{Cu}(\mathrm{N}-\mathrm{O})(\mathrm{N}-\mathrm{N})\left(\mathrm{ClO}_{4}\right)_{2}\right]$, in which $\mathrm{N}-\mathrm{O}=4$-fluorophenoxyacetic acid hydrazide (4-FH) or 4-nitrobenzoic hydrazide (4-NH) and $\mathrm{N}-\mathrm{N}=1,10$-phenanthroline (phen), 4-4'dimethoxy-2-2'-bipyridine $(\mathrm{dmb})$ or 2,2-bipyridine (bipy) were synthesized and characterized using various spectroscopic methods. The X-ray structural analysis of one representative compound indicates that the geometry around the copper ion is distorted octahedron, in which the ion is coordinated to hydrazide via the terminal nitrogen and the carbonyl oxygen, and to heterocyclic bases via their two nitrogen atoms. Two perchlorate anions occupy the apical positions, completing the coordination sphere. The cytotoxic activity of compounds was investigated in three tumor cell lines (K562, MDA-MB-231 and MCF-7). Concerning K562 cell line, the complexes with 1,10-phenanthroline exhibit high cytotoxic activity and are more active than carboplatin, free ligands and $\left[\mathrm{Cu}(\mathrm{phen})_{2}\right]^{2+}$. Considering the cytotoxicity results, further investigations for the compounds $\left[\mathrm{Cu}(4-\mathrm{FH})(\right.$ phen $\left.)\left(\mathrm{ClO}_{4}\right)_{2}\right]$ I and $\left[\mathrm{Cu}(4-\mathrm{NH})(\right.$ phen $\left.)\left(\mathrm{ClO}_{4}\right)_{2}\right] \cdot \mathrm{H}_{2} \mathrm{O}$ III were performed. Flow cytometric analysis revealed that these complexes induce apoptotic cell death in MDA-MB-231 cell line and bind to DNA with $\mathrm{K}$ values of $4.38 \times 10^{4}$ and $2.62 \times 10^{4}$, respectively. These compounds were also evaluated against wild type Mycobacterium tuberculosis (ATCC 27294) and exhibited antimycobacterial activity, displayed MIC values lower than those of the corresponding free ligands.
\end{abstract}

\section{Introduction}

Nowadays, there is a great interest in the use of copper complexes in cancer chemotherapy, mainly those containing $N, N$-heterocyclic ligands, such as 1,10-phenanthroline, 2,2'-bipyridine, 2,2':6',2"'terpyridine, and derivatives, that facilitate intercalation to DNA. After the report that $\left[\mathrm{Cu}(\mathrm{phen})_{2}\right]^{+}$complex cleaves DNA, a great number of copper complexes with $\mathrm{N}, \mathrm{N}$-donors ligands have been synthesized and utilized as artificial nucleases [1]. Moreover, many of these copper compounds have been described to inhibit tumoral cell growth [2-14]. Regarding the clinical utility of these complexes, two of them devel- oped by L. Ruiz and co-workers, are already approved for clinical trials as antitumor drugs $[15,16]$.

Our research group has a great interest in the synthesis and biological evaluation of ternary complexes of copper. As a first example, we reported the DNA cleavage ability of two copper(II)phenanthroline complexes with tetracycline and doxycycline. Both complexes showed an expressive plasmid DNA cleavage activity, under mild reaction conditions, even in the absence of any additional reducing agent, besides inhibited the growth of a chronic myelogenous leukemia cell line [17]. Furthermore, it was reported that UV-light exposure increases the cytotoxic activities of these copper complexes,

\footnotetext{
* Corresponding author at: Instituto de Química, Universidade Federal de Uberlândia, João Naves de Ávila Avenue, 2121, Campus Santa Mônica, 38.400-902 Uberlândia, MG, Brazil.

E-mail address: wendell.guerra@ufu.br (W. Guerra).
} 
which makes them potential agents for photodynamic therapy [18]. In other studies, our research group has also shown that copper(II) complexes containing $\beta$-diketones and 2,2'-bipyridine or 1,10-phenanthroline are promising antitumoral agents $[19,20]$. For example, the compound $\left[\mathrm{Cu}(\mathrm{L})(\mathrm{phen}) \mathrm{NO}_{3}\right]$, in which $\mathrm{L}=1$-(4-chlorophenyl)-4,4,4trifluoro-1,3-butanedione, inhibits the growth of K562 cells with an $\mathrm{IC}_{50}$ value equal to $2.1 \mu \mathrm{M}$ [19].

Regarding hydrazides and derivatives, it is known that these compounds exhibit a wide variety of biological activities, including antimycobacterial, antifungal, antibacterial, antioxidant, anti-inflammatory, and antitumoral, among others [21]. This class of compounds has the ability to readily coordinate to many transition metals. Therefore, several hydrazide complexes have been synthesized and characterized $[22,23]$. Some of these compounds exhibit remarkable biological properties, mainly antimycobacterial and antitumoral [24-32]. For instance, the effect of copper(II) complexes containing hydrazides and $N, N$-heterocyclic ligands on the growth of tumor cells was evaluated by our research group. These complexes were able to enter the cells and inhibit cellular growth in a concentration-dependent manner, with an activity higher than that of the corresponding free ligands [31]. Concerning the pharmacological potential of metal-based drugs, this work was, as much as is from our knowledge, the first to describe anticancer properties of copper(II) complexes with hydrazides and 1,10 phenanthroline or derivatives. In addition, more recently, Bortolotto et al. showed that under UV-light exposure, these complexes enhance the DNA cleavage activity [32]. Indeed, these results show clearly that ternary complexes of copper(II) with hydrazides and heterocyclic bases, such as 1,10-phenanthroline, are very promising as anticancer agents. Aiming to continue this work, we describe herein the synthesis of a new series of complexes containing hydrazides and $N, N$-heterocyclic ligands (Fig. 1). The new complexes were characterized by elemental analyses, conductivity measurements, high-resolution electrospray ionization mass spectrometry (HRESIMS), FT-IR, UV-Vis and EPR. Thereafter, DNA interactions, pro-apoptotic properties, cytotoxicity and antitubercular activity of the synthesized compounds were evaluated.

\section{Experimental}

\subsection{Starting materials}

The reagents (ligands and metallic salts) are commercially available (Sigma-Aldrich).

\subsection{Physical measurements}

Conductivity studies were carried out with a Tecnal Tec-4MP conductivity meter using a cell of constant $1.03 \mathrm{~cm}^{-1}$. Spectroscopic grade methanol (Sigma-Aldrich) $\left(\Lambda_{\mathrm{M}}=2.13 \mu \mathrm{s} / \mathrm{cm}\right)$ was used as solvent.

Elemental analyses were performed using a Perkin-Elmer $2400 \mathrm{CHN}$ Elemental Analyzer.

Infrared spectra were obtained on a PerkinElmer Spectrum Two spectrophotometer equipped with an attenuated total reflectance (ATR) sample holder and ZnSe crystal. The spectra were recorded in the range of $4000-600 \mathrm{~cm}^{-1}$.

Diffuse reflectance spectra and UV-Vis were obtained on a Shimadzu UV-2501 PC spectrophotometer.

High-resolution electrospray ionization mass spectra (HRESIMS) were measured on an ultrOTOF (Bruker Daltonics) spectrometer, operating in the positive mode. Methanol was used as solvent system and the samples were infused into the ESI source at a flow rate of $5 \mu \mathrm{L} /$ min. The calculated values for the charged complex ions were made using ChemDraw Ultra 15.0.

To register EPR spectra of the metal complexes, a Bruker instrument (Karlsruhe, Germany) model EMX was used, operating at X-band ( $9.50 \mathrm{GHz}$ frequency, $20 \mathrm{~mW}$ power, $100 \mathrm{kHz}$ modulation frequency), at $77 \mathrm{~K}$. Samples in solid or as frozen methanol solution were used, in Wilmad quartz tubes, and frequency calibration was provided with DPPH ( $\alpha, \alpha^{\prime}$-diphenyl- $\beta$-picrylhydrazyl; $g=2.0036$ ).

\subsection{Crystal structure determination}

The data collection was performed at room temperature (296 K) using Mo-K $\alpha$ radiation $(\lambda=0.71073 \AA)$ on a BRUKER APEX II Duo diffractometer. Standard procedures were applied for data reduction and absorption correction. The structure was solved with SHELXS97 using direct methods [33] and refined by full-matrix least-square methods against $\mathrm{F}^{2}$ (SHELXL2014) [34]. All non-hydrogen atoms were refined with anisotropic displacement parameters with SHELXL2014 [34]. The hydrogen atoms were calculated at idealized positions using the riding model option of SHELXL2014 [34]. Crystallographic data, experimental details, data collection and refinement are reported in Table 1.

\subsection{Preparation of the complexes}

All complexes were prepared by the reaction of $\mathrm{Cu}\left(\mathrm{ClO}_{4}\right)_{2} \cdot 6 \mathrm{H}_{2} \mathrm{O}$<smiles>NNC(=O)COc1ccc(F)cc1</smiles>

$4-\mathrm{FH}$<smiles>NNC(=O)c1ccc([N+](=O)[O-])cc1</smiles>

$4-\mathrm{NH}$<smiles>c1cnc2c(c1)ccc1cccnc12</smiles>
phen

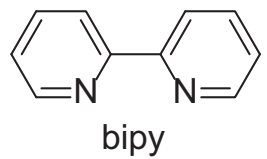<smiles>COc1ccnc(-c2cc(OC)ccn2)c1</smiles>

Fig. 1. Organic compounds used as ligands. 
Table 1

Crystal data and structure refinement for complex I.

\begin{tabular}{|c|c|}
\hline Empirical formula & $\mathrm{C}_{20} \mathrm{H}_{17} \mathrm{Cl}_{2} \mathrm{CuF} \mathrm{N} \mathrm{N}_{4} \mathrm{O}_{10}$ \\
\hline Formula weight & 626.82 \\
\hline Temperature & $296(2) \mathrm{K}$ \\
\hline Wavelength & $0.71073 \AA$ \\
\hline Crystal system & Monoclinic \\
\hline Space group & $\mathrm{P} 2{ }_{1} / \mathrm{c}$ \\
\hline \multirow[t]{2}{*}{ Unit cell dimensions } & $\mathrm{a}=18.6542(6) \AA$ \\
\hline & $\begin{array}{l}\mathrm{b}=13.7070(4) \AA \quad \AA=96.4240(10)^{\circ} \\
\mathrm{c}=9.2529(3) \AA\end{array}$ \\
\hline Volume & $2351.05(13) \AA^{3}$ \\
\hline $\mathrm{Z}$ & 4 \\
\hline Density (calculated) & $1.771 \mathrm{Mg} / \mathrm{m}^{3}$ \\
\hline Absorption coefficient & $1.230 \mathrm{~mm}^{-1}$ \\
\hline $\mathrm{F}(000)$ & 1268 \\
\hline Crystal size & $0.40 \times 0.12 \times 0.09 \mathrm{~mm}^{3}$ \\
\hline$\theta$ range for data collection & 1.098 to $26.394^{\circ}$ \\
\hline Index ranges & $\begin{array}{l}-23<=\mathrm{h}<=23,-17<=\mathrm{k}<=17 \\
-11<=1<=11\end{array}$ \\
\hline Reflections collected & 42,766 \\
\hline Independent reflections & $4816[\mathrm{R}(\mathrm{int})=0.0274]$ \\
\hline $\begin{array}{l}\text { Completeness to } \\
\text { theta }=25.242\end{array}$ & $100.0 \%$ \\
\hline Absorption correction & Multi-scan \\
\hline Max. and min. Transmission & 0.7454 and 0.6596 \\
\hline Refinement method & Full-matrix least-squares on $\mathrm{F}^{2}$ \\
\hline Data/restraints/parameters & $4816 / 14 / 381$ \\
\hline Goodness-of-fit on $\mathrm{F}^{2}$ & 1.043 \\
\hline $\begin{array}{l}\text { Final } \mathrm{R} \text { indices }[I>2 \text { sigma } \\
\quad(\mathrm{I})]\end{array}$ & $R_{1}=0.0401, \mathrm{w} R_{2}=0.1082$ \\
\hline $\mathrm{R}$ indices (all data) & $R_{1}=0.0473, \mathrm{w} R_{2}=0.1138$ \\
\hline Extinction coefficient & $\mathrm{n} / \mathrm{a}$ \\
\hline Largest diff. Peak and hole & 0.687 and -0.547 e. $\AA^{-3}$ \\
\hline
\end{tabular}

$(0.09 \mathrm{~g}, 0.25 \mathrm{mmol})$ with $0.25 \mathrm{mmol}$ of hydrazide dissolved in a minimum amount of methanol. The mixture was stirred for $2 \mathrm{~h}$, followed by the addition of $N, N$-donor heterocyclic ligand $(0.25 \mathrm{mmol})$ previously dissolved in methanol. After $48 \mathrm{~h}$, the compound was filtered, washed with methanol and dried under reduced pressure.

\section{a. $\left[\mathrm{Cu}(4-\mathrm{FH})(\right.$ phen $\left.)\left(\mathrm{ClO}_{4}\right)_{2}\right] \mathrm{I}$.}

M.M.: $626.82 \mathrm{~g} \mathrm{~mol}^{-1}$. Yield: $75 \%$. Color: Blue. Anal. Calc. for $\left(\mathrm{CuC}_{20} \mathrm{H}_{17} \mathrm{FN}_{4} \mathrm{O}_{10} \mathrm{Cl}_{2}\right)$ : C, 38.32; H, 2.73; N, 8.94\%. Found: C, 38.68; H, 2.77; N, 8.90\%. (+)-HRESIMS (methanol), $m / z: 426.0555$ [M - 2ClO $4-$ $\mathrm{H}^{+}$(calc. For $\mathrm{C}_{20} \mathrm{H}_{16} \mathrm{CuFN}_{4} \mathrm{O}_{2}, 426.0548(\Delta 1.6 \mathrm{ppm}$ )). IR (ATR) $\nu$ $\left(\mathrm{cm}^{-1}\right): 3262,3204,3069,1661,1588,1525,1511,1434,1371,1250$, 1221, 1138, 1100, 1088, 1049, 927, 878, 854, 830, 780, 742, 721, 652, 615. UV-Vis (methanol), $\lambda_{\max }(\mathrm{nm})=293\left(1.1 \times 10^{4} \mathrm{M}^{-1} \mathrm{~cm}^{-1}\right)$, $272\left(3.5 \times 10^{4} \mathrm{M}^{-1} \mathrm{~cm}^{-1}\right), \quad 220 \quad\left(3.7 \times 10^{4} \mathrm{M}^{-1} \mathrm{~cm}^{-1}\right), \quad 640$ $\left(2.9 \times 10^{1} \mathrm{M}^{-1} \mathrm{~cm}^{-1}\right), 610$ (solid). EPR parameters (in methanol frozen solution): $\mathrm{g}_{\perp} 2.063 ; \mathrm{g}_{/ /} 2.255 ; \mathrm{A} / / 185 \times 10^{-4} \mathrm{~cm}^{-1}$. Molar conductivity, $\Lambda \mathrm{M}$ (methanol) $=188.45 \mu \mathrm{S} \mathrm{cm}^{-1}$.

\section{b. $\left[\mathrm{Cu}(4-\mathrm{FH})(\mathrm{dmb})\left(\mathrm{ClO}_{4}\right)_{2}\right] \cdot \mathrm{H}_{2} \mathrm{O}$ II}

M.M.: $680.86 \mathrm{~g} \mathrm{~mol}^{-1}$. Yield: 51\%. Color: Blue. Anal. Calc. for $\left(\mathrm{CuC}_{20} \mathrm{H}_{23} \mathrm{FN}_{4} \mathrm{O}_{13} \mathrm{Cl}_{2}\right)$ : C, 35.28; $\mathrm{H}, 3.40 ; \mathrm{N}, 8.23 \%$. Found: C, 34.85; H, 3.56; N, 7.81\%. (+)-HRESIMS (methanol), $m / z: 462.0760$ $\left[\mathrm{M}-2 \mathrm{ClO}_{4}-\mathrm{H}\right]^{+}$(calc. for $\mathrm{C}_{20} \mathrm{H}_{20} \mathrm{CuFN}_{4} \mathrm{O}_{4}, 462.0759(\Delta 0.2 \mathrm{ppm})$ ). IR (ATR) $\nu\left(\mathrm{cm}^{-1}\right): 3613,3256,3094,2980,1669,1614,1562,1506$, $1476,1444,1424,1370,1342,1322,1288,1272,1264,1251,1229$, 1217, 1087, 1048, 1030, 1010, 970, 920, 889, 859, 832, 778, 742. UV-Vis (methanol), $\lambda_{\max }(\mathrm{nm})=299\left(1.4 \times 10^{4} \mathrm{M}^{-1} \mathrm{~cm}^{-1}\right), 286$ $\begin{array}{lll}\left(1.7 \times 10^{4} \mathrm{M}^{-1} \mathrm{~cm}^{-1}\right), & 277 \quad\left(1.8 \times 10^{4} \mathrm{M}^{-1} \mathrm{~cm}^{-1}\right), & 229\end{array}$ $\left(6.4 \times 10^{4} \mathrm{M}^{-1} \mathrm{~cm}^{-1}\right), 635\left(2.6 \times 10^{1} \mathrm{M}^{-1} \mathrm{~cm}^{-1}\right), 607$ (solid). EPR parameters (in methanol frozen solution): $g_{\perp} 2.058 ; g_{/ /} 2.244 ; A_{/ /}$ $188 \times 10^{-4} \mathrm{~cm}^{-1}$. Molar conductivity, $\Lambda \mathrm{M}$ (methanol)
$=176.01 \mu \mathrm{S} \mathrm{cm}{ }^{-1}$.

\section{c. $\left[\mathrm{Cu}(4-\mathrm{NH})(\right.$ phen $\left.)\left(\mathrm{ClO}_{4}\right)_{2}\right] \cdot \mathrm{H}_{2} \mathrm{O}$ III}

M.M.: $641.81 \mathrm{~g} \mathrm{~mol}^{-1}$. Yield: 54\%. Color: Blue. Anal. Calc. for $\left(\mathrm{CuC}_{19} \mathrm{H}_{17} \mathrm{~N}_{5} \mathrm{O}_{12} \mathrm{Cl}_{2}\right)$ : C, 35.56; H, 2.67; N, 10.91\%. Found: C, 35.95; $\mathrm{H}$, 2.68; N, 10.92\%. (+)-HRESIMS (methanol), $m / z: 423.0399$ [M - 2ClO $-\mathrm{H}]^{+}$(calc. For $\mathrm{C}_{19} \mathrm{H}_{14} \mathrm{CuN}_{5} \mathrm{O}_{3}, 423.0387(\Delta 2.8 \mathrm{ppm})$ ). IR (ATR) $\nu$ $\left(\mathrm{cm}^{-1}\right)$ : 3509, 3461, 3236, 3166, 3092, 3070, 2978, 2915, 1653, 1619, $1574,1522,1493,1431,1368,1350,1322,1236,1160,1133,1101$, 1088, 1054, 1011, 924, 866, 856, 826, 788, 741, 721, 710. UV-Vis (methanol), $\lambda_{\max }(\mathrm{nm})=293 \quad\left(2 . \quad 2 \times 10^{4} \mathrm{M}^{-1} \mathrm{~cm}^{-1}\right), \quad 272$ $\left(5.6 \times 10^{4} \mathrm{M}^{-1} \mathrm{~cm}^{-1}\right), \quad 224 \quad\left(4.8 \times 10^{4} \mathrm{M}^{-1} \mathrm{~cm}^{-1}\right), \quad 206$ $\left(5.1 \times 10^{4} \mathrm{M}^{-1} \mathrm{~cm}^{-1}\right), 632\left(3.5 \times 10^{1} \mathrm{M}^{-1} \mathrm{~cm}^{-1}\right), 608$ (solid). EPR parameters (in methanol frozen solution): $\mathrm{g}_{\perp} 2.062 ; \mathrm{g}_{/ /} 2.254 ; \mathrm{A} / /$ $183 \times 10^{-4} \mathrm{~cm}^{-1}$. Molar conductivity, $\Lambda \mathrm{M}$ (methanol) $=168.19 \mu \mathrm{S} \mathrm{cm}^{-1}$.

\section{d. $\left[\mathrm{Cu}(4-\mathrm{NH})\left(\right.\right.$ bipy) $\left.\left(\mathrm{ClO}_{4}\right)_{2}\right] \cdot \mathrm{H}_{2} \mathrm{O}$ IV}

M.M.: $617.79 \mathrm{~g} \mathrm{~mol}^{-1}$. Yield: $60 \%$. Color: Blue. Anal. Calc. for $\left(\mathrm{CuC}_{17} \mathrm{H}_{17} \mathrm{~N}_{5} \mathrm{O}_{12} \mathrm{Cl}_{2}\right)$ : C, 33.05; H, 2.77; N, 11.34\%. Found: C, 33.43; $\mathrm{H}$, 2.68; N, 11.12\%. (+)-HRESIMS (methanol), $m / z: 399.0393$ [M - 2ClO 4 - $\mathrm{H}]^{+}$(calc. For $\mathrm{C}_{17} \mathrm{H}_{14} \mathrm{CuN}_{5} \mathrm{O}_{3}, 399.0387$ ( $\Delta 1.5 \mathrm{ppm}$ )). IR (ATR) $\nu$ $\left(\mathrm{cm}^{-1}\right): 3534,3475,3240,3172,3116,3085,3038,2979,2902,2858$, $1650,1618,1610,1601,1574,1522,1496,1476,1448,1348,1321$, $1249,1227,1178,1127,1110,1089,1056,1034,1013,933,909,866$, 852, 825, 778, 731, 709, 666. UV-Vis (methanol), $\lambda_{\max }(\mathrm{nm})=310$ $\left(2.4 \times 10^{4} \mathrm{M}^{-1} \mathrm{~cm}^{-1}\right), \quad 298 \quad\left(2.7 \times 10^{4} \mathrm{M}^{-1} \mathrm{~cm}^{-1}\right), \quad 249$ $\left(3.0 \times 10^{4} \mathrm{M}^{-1} \mathrm{~cm}^{-1}\right), \quad 206 \quad\left(3.4 \times 10^{4} \mathrm{M}^{-1} \mathrm{~cm}^{-1}\right), \quad 203$ $\left(3.6 \times 10^{4} \mathrm{M}^{-1} \mathrm{~cm}^{-1}\right), 625\left(1.3 \times 10^{1} \mathrm{M}^{-1} \mathrm{~cm}^{-1}\right), 605$ (solid). Molar conductivity, $\Lambda \mathrm{M}($ methanol $)=191.75 \mu \mathrm{cm}^{-1}$.

\section{e. $\left[\mathrm{Cu}(4-\mathrm{NH})(\mathrm{dmb})\left(\mathrm{ClO}_{4}\right)_{2}\right] \cdot \mathrm{H}_{2} \mathrm{O}$ V}

M.M.: $677.84 \mathrm{~g} \mathrm{~mol}^{-1}$. Yield: $73 \%$. Color: Blue. Anal. Calc. for $\left(\mathrm{CuC}_{19} \mathrm{H}_{21} \mathrm{~N}_{5} \mathrm{O}_{14} \mathrm{Cl}_{2}\right)$ : C, 33.67; $\mathrm{H}, 3.12 ; \mathrm{N}, 10.33 \%$. Found: $\mathrm{C}, 33.40 ; \mathrm{H}$, 2.97; N, 10.00\%. (+)-HRESIMS (methanol), $m / z: 459.0606\left[\mathrm{M}-2 \mathrm{ClO}_{4}\right.$ $-\mathrm{H}]^{+}$(calc. for $\mathrm{C}_{19} \mathrm{H}_{18} \mathrm{CuN}_{5} \mathrm{O}_{5}, 459.0598$ ( $\left.\Delta 1.7 \mathrm{ppm}\right)$ ). IR (ATR) $\nu$ $\left(\mathrm{cm}^{-1}\right)$ : 3610, 3257, 3180, 3125, 3090, 2972, 2912, 2848, 1652, 1609, 1573, 1558, 1533, 1499, 1474, 1440, 1417, 1347, 1323, 1283, 1251, 1222, 1128, 1093, 1063, 1044, 1013, 970, 931, 907, 871, 852, 838, 709. UV-Vis (methanol), $\lambda_{\max }(\mathrm{nm})=299\left(2.7 \times 10^{4} \mathrm{M}^{-1} \mathrm{~cm}^{-1}\right)$, $287\left(3.2 \times 10^{4} \mathrm{M}^{-1} \mathrm{~cm}^{-1}\right), \quad 229 \quad\left(8.4 \times 10^{4} \mathrm{M}^{-1} \mathrm{~cm}^{-1}\right), \quad 622$ (7.1 $\mathrm{M}^{-1} \mathrm{~cm}^{-1}$ ), 604 (solid). Molar conductivity, $\Lambda \mathrm{M}$ (methanol) $=214.60 \mu \mathrm{sm}^{-1}$.

\subsection{Cells and culture}

\subsubsection{K562 cells}

The K562 cell line was purchased from the Rio de Janeiro Cell Bank (number CR083 of the RJCB collection). This cell line was established from pleural effusion of a 53 year-old female with chronic myelogenous leukemia in terminal blast crisis. Cells were cultured in RPMI 1640 (Sigma Chemical Co.) medium supplemented with $10 \%$ fetal calf serum (CUlTILAB, São Paulo, Brazil) at $37{ }^{\circ} \mathrm{C}$ in a humidified $5 \% \mathrm{CO}_{2}$ atmosphere. Cultures grow exponentially from $10^{5}$ cells $\mathrm{mL}^{-1}$ to about $8 \times 10^{5}$ cells $\mathrm{mL}^{-1}$ in three days. Cell viability was checked by Trypan Blue exclusion. The cell number was determined by Coulter counter analysis.

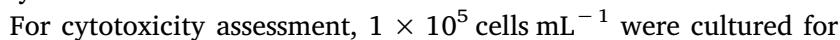
$72 \mathrm{~h}$ in the absence and presence of a range of concentrations of tested compounds. The sensitivity to compound was evaluated by the concentration that inhibits cell growth by $50 \%$ ( IC $_{50}$ ). Stock solutions were prepared in DMSO and diluted accordingly to obtain the concentrations used in the cytotoxic assays. The final concentration of 
DMSO in the experiments was below $0.5 \%$ and we have checked that the solvent has no effect in cell growth at this concentration.

\subsubsection{Human breast cancer cell lines}

The MDA-MB-231 and MCF-7 cell lines were purchased from the Rio de Janeiro Cell Bank. MCF-7 and MDA-MB-231 cells were cultured in DMEM medium supplemented with $10 \%$ fetal bovine serum, 100 units/ $\mathrm{mL}$ penicillin, $100 \mathrm{mg} / \mathrm{mL}$ streptomycin, $\mathrm{pH} 7.4$ at $37^{\circ} \mathrm{C}$ with $5 \% \mathrm{CO}_{2}$, in humid chamber, to reach $\approx 80 \%$ confluence for assays. Cells detachments for subculture/plating were done with a trypsin/EDTA solution for MCF-7 cells and EDTA solution for MDA-MB-231 cells, for 5 min; trypsin inactivation was carried out with BFS when applied and the cells were washed three times with medium. The cell number was determined by Neubauer chamber Counter analysis.

For cytotoxicity assessment, $5 \times 10^{4}$ cells $\mathrm{mL}^{-1}$ were cultured for $36 \mathrm{~h}$ in the absence and the presence of a range of concentrations of tested compounds. The sensitivity to compound was evaluated by the concentration that inhibits cell growth by $50 \%\left(\mathrm{IC}_{50}\right)$. Stock solutions of the compounds were prepared in DMSO.

\subsubsection{Determination of cell death mode - flow cytometric analysis}

The Annexin V/Dead Cell kit utilizes a fluorescent dye conjugated to Annexin- $\mathrm{V}$ to detect phosphatidylserine on the external membrane of apoptotic cells and a cell death dye 7-AAD that provides information on the membrane integrity or cell death. 7-AAD is excluded from living healthy cells, as well as early apoptotic cells. By observing the events of graphical plots populations of cells were classified into four distinguished groups: Viable cells: Annexin $(-)$ and 7-AAD (-), lower-left quadrant $\left(\mathrm{Q}_{4}\right)$; Early apoptotic cells: Annexin $(+)$ and 7-AAD (-), lower right quadrant $\left(\mathrm{Q}_{3}\right)$; Late apoptotic cells: Annexin $(+)$ and 7-AAD $(+)$, upper-right quadrant $\left(\mathrm{Q}_{2}\right)$. Cells that have died through non-apoptotic pathway: Annexin $\mathrm{V}(-)$ and 7-AAD $(+)$, upper-left quadrant $\left(\mathrm{Q}_{1}\right)$. MDA-MB-231 cells were seeded in a 24-well culture plate at a density of $3 \times 10^{5}$ cells/well and were cultured overnight in RPMI supplemented with $5 \%$ fetal bovine serum. In the next day cells were exposed to $50 \mu \mathrm{M}$ of the complexes I and III for $24 \mathrm{~h}$. MDA-MB-231 cells were harvested by trypsinisation and analyzed for the detection of early/late apoptosis and cell death mode using Annexin V/Dead Cell and 7-AAD.

\subsection{Anti-Mycobacterium tuberculosis activity assay}

The anti-MTB activity of the compounds was determined by the REMA (Resazurin Microtiter Assay) method [35]. Stock solutions of the tested compounds were prepared in DMSO at $10 \mathrm{mg} / \mathrm{mL}$ and diluted in Middlebrook 7H9 broth (Difco) supplemented with oleic acid, albumin, dextrose and catalase (OADC), performed by Precision XS (Biotek ${ }^{\circledast}$ ) to obtain the final drug concentration range of $0.09-25 \mu \mathrm{g} / \mathrm{mL}$. Rifampicin was dissolved in DMSO and was used as standard drugs. A suspension of the $M$. tuberculosis H37Rv ATCC 27294 was cultured in Middlebrook 7H9 broth supplemented with OADC and $0.05 \%$ Tween 80 . When the culture obtained a turbidity of McFarland standard No. 1, it was adjusted by $5 \times 10^{5} \mathrm{CFU}$ per $\mathrm{mL}$ and $100 \mu \mathrm{L}$ of the inoculum were added to each well of a 96-well microplate (Kasvi ${ }^{\circledR}$ ) together with $100 \mu \mathrm{L}$ of the compounds. Samples were set up in triplicate. The plates were incubated for 7 days at $37^{\circ} \mathrm{C}$. Resazurin (solubilized in water) was added ( $30 \mu \mathrm{L}$ of $0.01 \%$ ). The fluorescence of the wells was read after $24 \mathrm{~h}$ with a Cytation 3 (Biotek ${ }^{\circledast}$ ). The MIC was defined as the lowest concentration resulting in $90 \%$ inhibition of growth of MTB.

\subsection{DNA binding}

A Cary100 Varian spectrometer was used for UV and visible absorption measurements. For the interactions with CT DNA, the complex concentration used was $2.5 \times 10^{-5} \mathrm{M}$ and the DNA concentration varied from 0 to $3 \times 10^{-4} \mathrm{M}$. The DNA concentration per nucleotide was determined by the $\varepsilon=6600 \mathrm{M}^{-1} \mathrm{~cm}^{-1}$ at $260 \mathrm{~nm}$. The ionic strength was maintained constant with $1 \times 10^{-3} \mathrm{M} \mathrm{NaCl}$ and the $\mathrm{pH}$ was fixed at 7.3 with $20 \mathrm{mM}$ HEPES buffer. The absorbance of DNA itself was subtracted by adding equal quantity of DNA to both the complex and the reference solutions.

CD spectra were recorded in a Jasco J-815 spectropolarimeter in HEPES buffer $\left(20 \times 10^{-3} \mathrm{M}\right)$ pH 7.3. DNA concentration was $1 \times 10^{-4} \mathrm{M}$ and complex concentration varied from 0 to $3.2 \times 10^{-5} \mathrm{M}$. The absorbance of the complexes was subtracted from that of the reaction mixture.

\section{Results and discussion}

Ternary complexes of copper(II) of the type $[\mathrm{Cu}(\mathrm{N}-\mathrm{O})(\mathrm{N}-\mathrm{N})$ $\left.\left(\mathrm{ClO}_{4}\right)_{2}\right]$, in which $\mathrm{N}-\mathrm{O}=4$-fluorophenoxyacetic acid hydrazide (4$\mathrm{FH})$ or 4-nitrobenzoic hydrazide (4-NH); $\mathrm{N}-\mathrm{N}=1,10$-phenanthroline (phen), 4-4'-dimethoxy-2-2'-bipyridine (dmb) or 2,2-bipyridine (bipy) were synthesized. The complexes were characterized by elemental analyses, conductivity measurements and spectroscopic methods. In addition, complex I was analyzed by single crystal X-ray diffraction. All the copper complexes are colorful, non-hygroscopic, stable to air and light and soluble in organic solvents such as methanol, DMSO and acetonitrile.

The results of elemental analyses, which are given in experimental section, are in accordance with the proposed structures. The molar conductance measurements of the complexes were performed in methanol $\left(1 \times 10^{-3} \mathrm{M}\right)$ at room temperature. The values varied between 168.19 and $214.60 \mu \mathrm{S} \mathrm{cm}^{-1}$, depending of the complex, which indicates that they are 1:2 electrolytes [31]. The labilization of the axial ligands in solution (perchlorate anions) results in the generation of compounds of type $[\mathrm{Cu}(\mathrm{N}-\mathrm{O})(\mathrm{N}-\mathrm{N})]^{2+}[17,19]$.

The high-resolution mass spectra of the copper complexes were recorded. The water molecules present in the molecular structures of II-V were dissociated from the complexes in the ionization process. The $\mathrm{m} / \mathrm{z}$ values listed in the experimental section refer to the peak containing the most abundant isotope $\left({ }^{63} \mathrm{Cu}\right)$. For instance, mass spectrum of the complex $\mathbf{V}$ exhibited the charged ion at $\mathrm{m} / \mathrm{z} 459.0606$ $\left[\mathrm{M}-2 \mathrm{ClO}_{4}-\mathrm{H}\right]^{+}$that was close to the calculated value for $\mathrm{C}_{19} \mathrm{H}_{18} \mathrm{CuN}_{5} \mathrm{O}_{5}, 459.0598(\Delta 1.7 \mathrm{ppm}$ ), and represents the pattern observed for all compounds (Fig. 2) [36].

In the IR spectra of the complexes II-V, a broad band at $3550 \mathrm{~cm}^{-1}$ indicates the presence of one water molecule. For all complexes, a group of bands between 2900 and $3080 \mathrm{~cm}^{-1}$ corresponds to the $\nu \mathrm{C}-\mathrm{H}$ stretching vibration. Two intense bands between 1085 and $1045 \mathrm{~cm}^{-1}$ are attributable to the presence of two unidentate perchlorate ions [37]. Hydrazides show characteristic absorptions between 3332 and $3150 \mathrm{~cm}^{-1}$ which are attributable to the $\mathrm{NH}_{2}$ and $\mathrm{NH}$ groups $[22,23]$. In all complexes studied, the bands originating from $\mathrm{NH}_{2}$ group showed considerable shift as compared to the free ligands. An absorption assigned to $\nu \mathrm{C}=\mathrm{O}$ around $1666-1645 \mathrm{~cm}^{-1}$ corroborates with the proposed structures.

Electronic absorption spectra of all compounds were performed in methanol $\left(10^{-5} \mathrm{M}\right)$. A red shift in relation to free ligands confirms the presence of the complexes in solution [31]. The complexes possess only one broad and asymmetric $\mathrm{d}-\mathrm{d}$ band centered at $\approx 630 \mathrm{~nm}$. For example, the complex IV exhibits a d-d band centered at $625 \mathrm{~nm}$ $\left(\varepsilon=13 \mathrm{M}^{-1} \mathrm{~cm}^{-1}\right.$ ). These observations are consistent with a distortion from the octahedron geometry due to the Jahn-Teller effect [19]. In the solid state, all complexes exhibit the same $\mathrm{d}-\mathrm{d}$ band centered at $\approx 608 \mathrm{~nm}$, indicating that the geometry of the complexes in solution differs from that in solid state $[19,20]$. Moreover, in the solid state, the complexes exhibited a new band (CT) around $480 \mathrm{~nm}$.

From EPR data, the corresponding parameters were determined for the studied copper(II) complexes (Table 2). The obtained values were very close, indicating a tetragonal arrangement of the ligands around the copper center, with a small tetrahedral distortion, as estimated by the empirical ratio $\mathrm{g}_{/ /} / \mathrm{A}_{/ / /}[31]$, around $120 \mathrm{~cm}$. In the solid state, all 


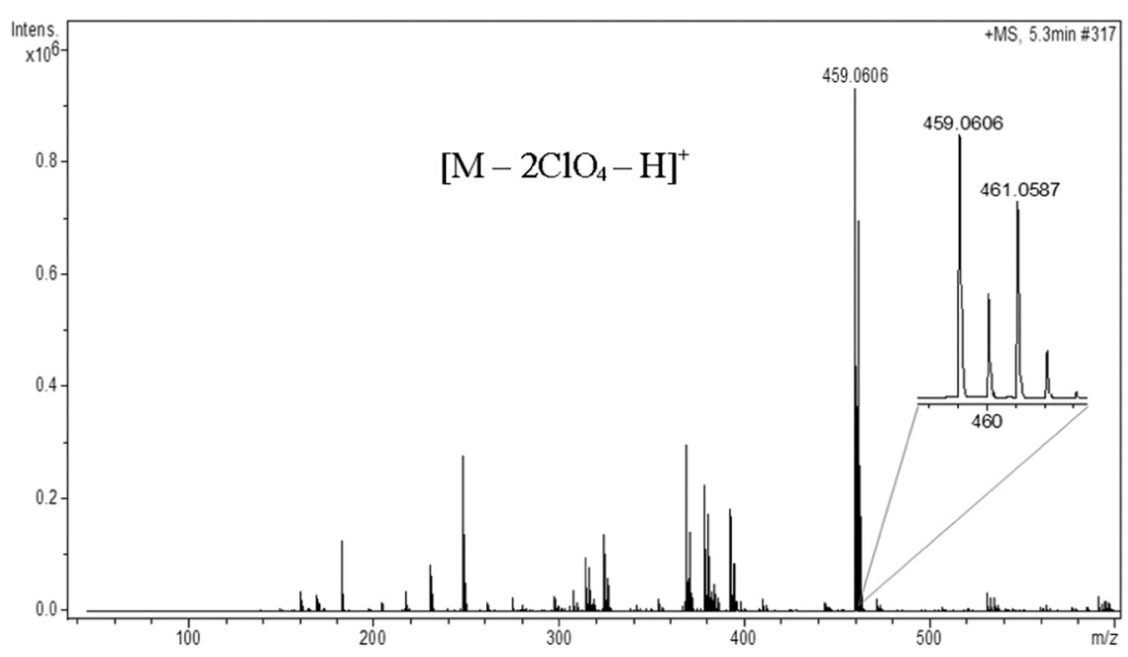

Fig. 2. (+)-HRESI-MS spectrum of complex V (charged complex ion observed was $\left[\mathrm{M}-2 \mathrm{ClO}_{4}-\mathrm{H}\right]^{+}$).

Table 2

EPR parameters for copper(II) complexes in solid state and in methanol frozen solution, at $77 \mathrm{~K}$.

\begin{tabular}{lllllll}
\hline Complex & $\mathrm{g}_{\text {iso }}{ }^{\#}$ & $\mathrm{~g}_{\perp}$ & $\mathrm{g} / /$ & $\mathrm{A} / /(\mathrm{G})$ & $\mathrm{A}_{/ /}\left(10^{-4} \mathrm{~cm}^{-1}\right)^{\S}$ & $\mathrm{g}_{/ /} / \mathrm{A}_{/ /}(\mathrm{cm})$ \\
\hline I & 2.065 & 2.063 & 2.255 & 176 & 185 & 122 \\
II & 2.065 & 2.058 & 2.244 & 179 & 188 & 119 \\
III & 2.071 & 2.062 & 2.254 & 174 & 183 & 123 \\
\hline
\end{tabular}

\# In solid state.

${ }^{\S} \mathbf{A}_{/ /}\left(\right.$in $\left.10^{-4} \mathrm{~cm}^{-1}\right)=g_{/ /} \beta A_{/ /}$(in $\left.\mathrm{G}\right)=0.46686 \times 10^{-4} \mathrm{~g}_{/ /} \mathrm{A}_{/ /}$(in G); where $\beta=1.39969 \mathrm{MHz} / \mathrm{G}$.

the compounds exhibited only an isotropic $g_{\text {iso }}$ value, 2.065 to 2.071 .

\subsection{Crystal structure}

Blue crystals suitable for single crystal X-ray diffraction were obtained for complex I after slow evaporation of a methanol/toluene solution at room temperature. The crystals thereby formed were collected, washed with water and dried under reduced pressure. Single crystal X-ray analysis demonstrates that complex I crystallizes in the monoclinic system, space group $P 2_{1} / c$. Fig. 3 illustrates the molecular structure of the complex I along with atomic labeling scheme. As it can be seen, the complex I exhibits a distorted octahedral geometry around $\mathrm{Cu}(\mathrm{II})$ ion, in which the ligands are coordinated in a bidentate mode. The equatorial site is occupied by two nitrogen atoms from phen (N3 and N4) and two atoms from 4-FH ligand (O1 and N2). The apical sites are occupied by two oxygen atoms (O3a and O10a)

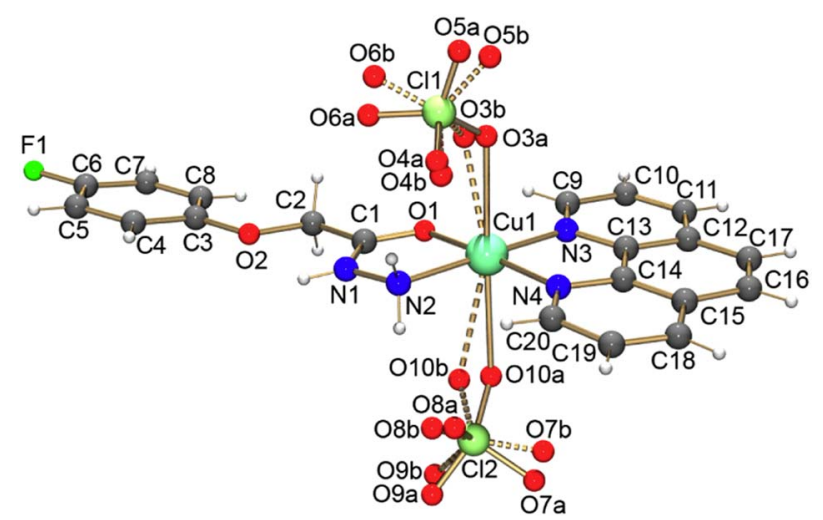

Fig. 3. Molecular structure of the complex $\left[\mathrm{Cu}(4-\mathrm{FH})(\mathrm{phen})\left(\mathrm{ClO}_{4}\right)_{2}\right]$ I showing oxygen atoms from the perchlorate disordered over two sites. Major component (solid lines) with $54.7 \%$ occupation and minor component (dashed lines) with $45.3 \%$ occupation. from two perchlorates weakly bonded [31]. The perchlorate anions are disordered over two sites. The solid lines (labeled a) indicate the bonds between the atoms with higher occupation factor (54.7\%), whereas the dashed lines (labeled b) represent the species with the lower occupation (45.3\%). Selected bond lengths and angles are reported in Table 3.

The $\mathrm{Cu} 1-\mathrm{O}$ bond lengths from the disordered perchlorate ions range from 2.4 to $2.8 \AA$. These values are considerably longer than the $\mathrm{Cu} 1-\mathrm{O}$ distance in the basal plane. This elongation can be explained by the Jahn-Teller effect [19]. The Cu1- $\mathrm{N}_{\text {phen }}(1.994(2)$ and 1.976(2) $\mathrm{A})$, $\mathrm{Cu} 1-\mathrm{N} 2(2.025(2) \AA)$ and $\mathrm{Cu} 1-\mathrm{O} 1(1.970(2) \AA)$ bond distances are normal and are comparable to those found for the related copper(II) complexes [31,38-41].

The basal geometry is considerably distorted from the perfect square-plane owing to the bite angle of the chelating phen ligand $\left(83.23(9)^{\circ}\right)$. The trans angles are $173.20(9)^{\circ}$ and $174.52(9)^{\circ}$. The values of bond lengths and angles are within the values expected for this class of compounds $[31,38]$. The bidentate chelation to the copper(II) ion by the ligands lead to the formation of two 5-membered planar rings and the root mean square (r.m.s) deviation to the fitted atoms is 0.0154 and $0.0124 \AA$. The angle between the mean planes formed by these rings is $7.27(13)^{\circ}$. The copper atom is in the equatorial plane and the r.m.s deviations of the five fitted atoms in the CuN3O plane are $0.0368 \AA$. The phen ligand is approximately planar and the r.m.s deviations to the fitted non-hydrogen atoms are $0.0251 \AA$. The copper ion is displaced about $0.050 \AA$ in relation to this plane.

The crystal structure is stabilized by hydrogen bonds (listed in Table 4) and weak $\pi-\pi$ stacking interactions. Intramolecular hydrogen bonds could be observed between the donor atoms of the 4-FH ligand and the oxygen atoms of the perchlorate groups $(\mathrm{N} 2 \cdots \mathrm{O} 8 \mathrm{a}=2.987(8)$

Table 3

Select bond lengths $[\AA ̊]$ and angles $\left[{ }^{\circ}\right]$ for complex I.

\begin{tabular}{ll}
\hline $\mathrm{Cu} 1-\mathrm{O} 1$ & $1.970(2)$ \\
\hline $\mathrm{Cu} 1-\mathrm{N} 2$ & $2.025(2)$ \\
$\mathrm{Cu} 1-\mathrm{N} 3$ & $1.976(2)$ \\
$\mathrm{Cu} 1-\mathrm{N} 4$ & $1.994(2)$ \\
$\mathrm{Cu} 1-\mathrm{O} 3 \mathrm{a}$ & $2.489(7)$ \\
$\mathrm{Cu} 1-\mathrm{O} 3 \mathrm{~b}$ & $2.412(10)$ \\
$\mathrm{Cu} 1-\mathrm{O} 10 \mathrm{a}$ & $2.601(7)$ \\
$\mathrm{Cu} 1-\mathrm{O} 10 \mathrm{~b}$ & $2.769(7)$ \\
N3-Cu1-N4 & $83.23(9)$ \\
O1-Cu1-N2 & $82.49(8)$ \\
$\mathrm{N} 4-\mathrm{Cu} 1-\mathrm{N} 2$ & $100.89(9)$ \\
$\mathrm{O} 1-\mathrm{Cu} 1-\mathrm{N} 3$ & $93.04(8)$ \\
O1-Cu1-N4 & $173.20(9)$ \\
N3-Cu1-N2 & $174.52(9)$ \\
\hline
\end{tabular}


Table 4

Hydrogen bonds for complex I [ $\AA$ and $\left.{ }^{\circ}\right]$.

\begin{tabular}{lllll}
\hline $\mathrm{D}-\mathrm{H} \cdots \mathrm{A}$ & $\mathrm{d}(\mathrm{D}-\mathrm{H})$ & $\mathrm{d}(\mathrm{H} \cdots \mathrm{A})$ & $\mathrm{d}(\mathrm{D} \cdots \mathrm{A})$ & $<(\mathrm{DHA})$ \\
\hline $\mathrm{N} 1-\mathrm{H} 1 \cdots \mathrm{O}^{\mathrm{O}} \mathrm{a}^{\# 1}$ & 0.86 & 2.38 & $2.846(7)$ & 114.3 \\
$\mathrm{~N} 1-\mathrm{H} 1 \cdots \mathrm{O} 9 \mathrm{a}^{\# 1}$ & 0.86 & 2.38 & $3.212(11)$ & 163.7 \\
$\mathrm{~N} 1-\mathrm{H} 1 \cdots \mathrm{O}^{\# 1}$ & 0.86 & 2.14 & $2.723(8)$ & 124.9 \\
$\mathrm{~N} 2-\mathrm{H} 2 \mathrm{a} \cdots \mathrm{O}$ a & 0.89 & 2.18 & $2.987(8)$ & 150.2 \\
$\mathrm{~N} 2-\mathrm{H} 2 \mathrm{a} \cdots \mathrm{O} 8 \mathrm{~b}$ & 0.89 & 2.07 & $2.881(9)$ & 151.5 \\
$\mathrm{~N} 2-\mathrm{H} 2 \mathrm{~b} \cdots \mathrm{O} 4 \mathrm{a}$ & 0.89 & 2.40 & $3.164(12)$ & 143.8 \\
$\mathrm{~N} 2-\mathrm{H} 2 \mathrm{~b} \cdots \mathrm{O} 4 \mathrm{~b}$ & 0.89 & 2.20 & $2.955(12)$ & 141.7
\end{tabular}

Symmetry transformations used to generate equivalent atoms: $\# 1 \mathrm{x},-\mathrm{y}+1 / 2, \mathrm{z}-1 / 2$.

$\AA$ and $\mathrm{N} 2 \cdots \mathrm{O} 4 \mathrm{a}=3.164(12) \AA$ ) as illustrated in Fig. S1 (Supplementary Material). The N1 nitrogen atom of the 4-FH ligand is a proton donor in two hydrogen bonds of the type $\mathrm{N}-\mathrm{H} \cdots \mathrm{O}$, involving the $\mathrm{O} 8$ and 09 oxygen atoms from perchlorate groups, resulting in chains that extend along [001] direction as depicted in Fig. S2 (Supplementary Material). Using complete graph-set analysis [42] to describe patterns in the hydrogen-bond network, we find $\mathrm{C}_{1}{ }^{2}(7)\left[\mathrm{R}_{1}{ }^{2}(4)\right]$. These chains connect into a three-dimensional architecture by $\pi-\pi$ stacking interactions among the phen moieties belonging to adjoining layers with centroid-centroid (Cg1-Cg2) distance of 3.770(1) Å for Cg1 (generated by the ring $\mathrm{C} 9 / \mathrm{C} 10 / \mathrm{C} 11 / \mathrm{C} 12 / \mathrm{C} 13 / \mathrm{N} 3$ ) and $\mathrm{Cg} 2$ (generated by ring C12-C17) (Fig. S3, Supplementary Material).

\subsection{Behavior in aqueous solution}

The complexes were evaluated by UV-Vis spectroscopy at different times in a mixture containing $\mathrm{H}_{2} \mathrm{O} / \mathrm{DMSO} 0.1 \%$. The values of absorbance and wavelength were not affected, even after $6 \mathrm{~h}$. These results indicate that the species $[\mathrm{Cu}(\mathrm{N}-\mathrm{O})(\mathrm{N}-\mathrm{N})]^{2+}$ remain intact in solution under the test conditions [19]. The spectra of a representative complex are reported in the Fig. 4.

\subsection{Cytotoxic studies and determination of cell death mode}

The cytotoxic activity of complexes is depicted in Table $5 . \mathrm{IC}_{50}$ values obtained for the free ligands, carboplatin and for the complex $\left.[\mathrm{Cu} \text { (phen })_{2}\right]\left(\mathrm{ClO}_{4}\right)_{2}$ are also shown for the sake of comparison.

Concerning K562 cell line, phen and 4-NH exhibit high activity. However, for the phenanthroline and its derivatives, it is assumed that the sequestering of trace metals in situ is involved and that the resulting metallic complexes are the active species [43]. The organic compounds bipy and dmb display moderate activity. In turn, the copper complexes inhibit the growth of $\mathrm{K} 562$ cells with $\mathrm{IC}_{50}$ values between 1.6 and $28 \mu \mathrm{M}$. As can be seen in the Table 5 , the order of cytotoxic activity is: III $>$ I $>$ V $>$ II $>$ IV. The copper complexes with 1,10-phenanthroline (phen) are more active than those with 4-4'-dimethoxy-2-2'-

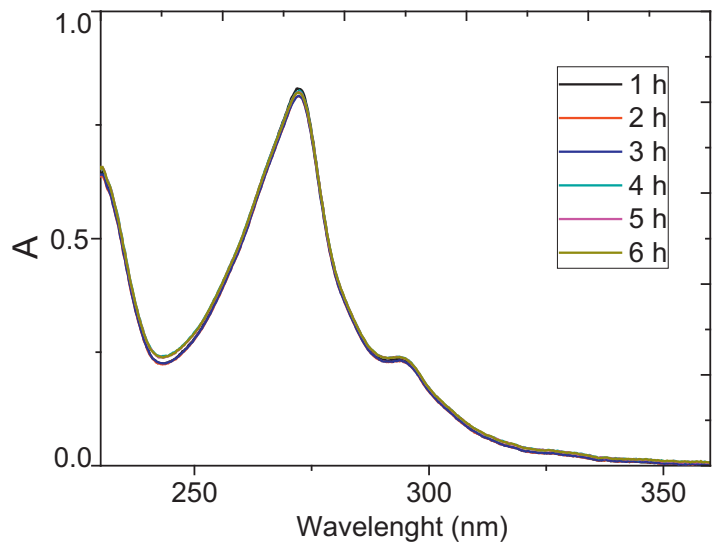

Fig. 4. Ultraviolet spectra of complex I as a function of time.
Table 5

$\mathrm{IC}_{50}(\mu \mathrm{M})$ values for ligands, complexes, $\left[\mathrm{Cu}(\mathrm{phen})_{2}\right]\left(\mathrm{ClO}_{4}\right)_{2}$ and carboplatin.a

\begin{tabular}{|c|c|c|c|}
\hline Compound & K562 (72 h) & $\begin{array}{l}\text { MDA-MB-231 } \\
(36 \mathrm{~h})\end{array}$ & MCF-7 (36 h) \\
\hline 4-FH & $>100$ & $>100$ & $>100$ \\
\hline 4-NH & 10.5 & $>100$ & $>100$ \\
\hline $\mathrm{dmb}$ & 23.5 & - & - \\
\hline bipy & 30.0 & - & - \\
\hline phen & 3.2 & $>100$ & $>100$ \\
\hline$\left[\mathrm{Cu}(4-\mathrm{FH})(\right.$ phen $\left.)\left(\mathrm{ClO}_{4}\right)_{2}\right] \mathbf{I}$ & 1.8 & 8.8 & 6.5 \\
\hline$\left[\mathrm{Cu}(4-\mathrm{FH})(\mathrm{dmb})\left(\mathrm{ClO}_{4}\right)_{2}\right] \cdot \mathrm{H}_{2} \mathrm{O}$ II & 26.2 & - & - \\
\hline $\begin{array}{l}{\left[\mathrm{Cu}(4-\mathrm{NH})(\mathrm{phen})\left(\mathrm{ClO}_{4}\right)_{2}\right] \cdot \mathrm{H}_{2} \mathrm{O}} \\
\quad \text { III }\end{array}$ & 1.6 & 5.5 & 4.6 \\
\hline $\begin{array}{l}{\left[\mathrm{Cu}(4-\mathrm{NH})(\mathrm{bipy})\left(\mathrm{ClO}_{4}\right)_{2}\right] \cdot \mathrm{H}_{2} \mathrm{O}} \\
\quad \text { IV }\end{array}$ & 28.0 & - & - \\
\hline$\underset{\mathbf{V}}{\left[\mathrm{Cu}(4-\mathrm{NH})(\mathrm{dmb})\left(\mathrm{ClO}_{4}\right)_{2}\right] \cdot \mathrm{H}_{2} \mathrm{O}}$ & 15.0 & - & - \\
\hline$\left[\mathrm{Cu}(\mathrm{phen})_{2}\right]\left(\mathrm{ClO}_{4}\right)_{2}$ & 3.4 & - & - \\
\hline Carboplatin & 10.0 & $>100$ & $>100$ \\
\hline
\end{tabular}

${ }^{\mathrm{a}} \mathrm{IC}_{50}$ is the concentration required to inhibit $50 \%$ of $\mathrm{K} 562$ cell growth.

bipyridine (dmb) and 2,2-bipyridine (bipy). In the literature, several studies have shown that copper(II) complexes with phenanthroline are more reactive than similar ones with bipyridine ligands [17,31,44]. An accepted explanation for this order of reactivity is that the planar polycyclic phen ring interacts better with DNA [45]. The cytotoxic activity of complexes I and III is higher than the activity of all corresponding free ligands, carboplatin and $\left[\mathrm{Cu}(\mathrm{Phen})_{2}\right]^{2+}$, a complex known by its nuclease action [31]. The complexes II, IV and V exhibit moderate to good activity against K562 cell line.

As it can be seen in Table 5, the complexes I and III were also very active against MDA-MB-231 and MCF-7 cells. It is worth noting that the free ligands and carboplatin exhibit $\mathrm{IC}_{50}$ values $>100 \mu \mathrm{M}$ against MDA-MB-231 and MCF-7 cells. In general, the cytotoxic activity of these compounds is similar to copper complexes with $\mathrm{N}, \mathrm{N}$-donor heterocyclic ligands already described [46-51,17,31], although, the mode of action can be quite different [19].

We have used flow cytometric analysis to determine whether the selected complexes I and III $(50 \mu \mathrm{M})$ are able to induce apoptosis. In accordance with our results, after $24 \mathrm{~h}$ incubation, the copper complexes I and III induce late apoptosis in MDA-MB-231 cell line (Fig. 5). Several copper(II) complexes were reported in literature by induce apoptosis, a form of programmed cell death that occurs in tumor cells as response to some anticancer agents [52-54].

\subsection{DNA binding}

We have registered the spectra of solutions of the complexes in the absence and in the presence of increasing concentrations of CT DNA. The addition of DNA induces a hypochromic effect and a minor batochromic shift, indicating that both complexes interact with calf thymus DNA. A representative experiment obtained with complexes I and III at $2.5 \times 10^{-5} \mathrm{M}$ and DNA concentration ranging from 0 a $3 \times 10^{-4} \mathrm{M}$ is shown in Figs. 6 and 7, respectively. In order to evaluate the binding strengths of the complexes, the binding constant, $\mathrm{K}$, was calculated accordingly to the equation.

$[D N A] /\left(\varepsilon_{\mathrm{a}}-\varepsilon_{\mathrm{f}}\right)=[\mathrm{DNA}] /\left(\varepsilon_{0}-\varepsilon_{\mathrm{f}}\right)+1 / \mathrm{K}\left(\varepsilon_{0}-\varepsilon_{\mathrm{f}}\right)$.

in which, [DNA] is the concentration of DNA in base pairs, $\varepsilon_{\mathrm{a}}$ is the ratio of the absorbance/[Cu], $\varepsilon_{\mathrm{f}}$ is the extinction coefficient of the free $\mathrm{Cu}^{\mathrm{II}}$ complex and $\varepsilon_{0}$ is the extinction coefficient of the complex in the fully bound form. The ratio of slope to intercept in the plot of [DNA]/ $\left(\varepsilon_{\mathrm{a}}-\varepsilon_{\mathrm{f}}\right)$ versus [DNA] gives the value of K (Figs. 6 and 7). The affinity of complex I to DNA is slightly higher than that complex III with $\mathrm{K}$ values of $4.38 \times 10^{4}$ and $2.62 \times 10^{4}$, respectively.

The high sensitivity of circular dichroism (CD) to conformational aspects makes this technique suitable to follow changes in DNA 
A

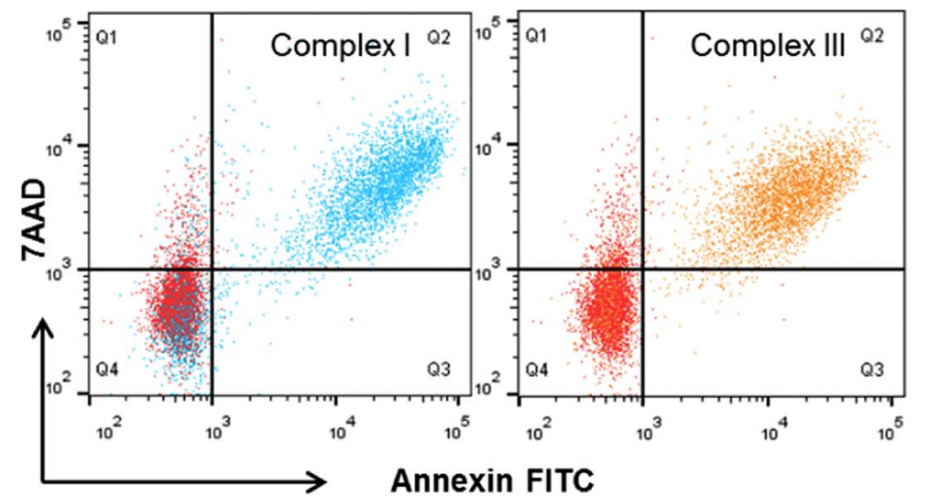

B

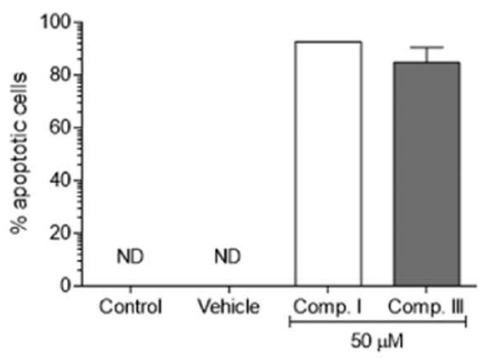

Fig. 5. Representative flow cytometry plots of MDA-MB-231 cell treated with complexes I and III.

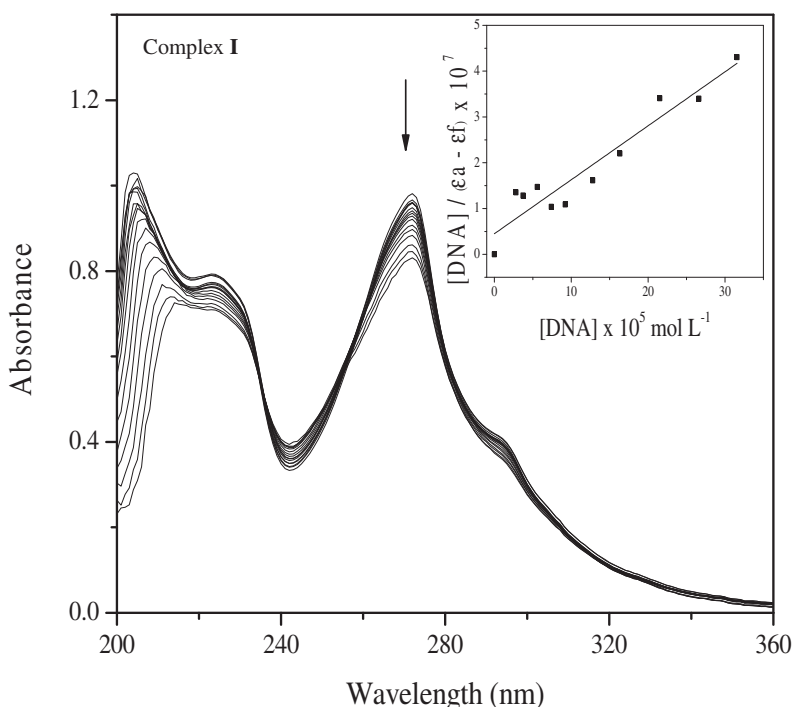

Fig. 6. Spectra of solutions containing complex $\mathbf{I}\left(2.5 \times 10^{-5} \mathrm{M}\right)$ and increasing concentrations of DNA in HEPES buffer pH 7.3. [DNA]: [complex I] ranging from 0 to 12. Inset: $[\mathrm{DNA}] /(\varepsilon \mathrm{a}-\varepsilon \mathrm{f})$ versus $[\mathrm{DNA}]$.

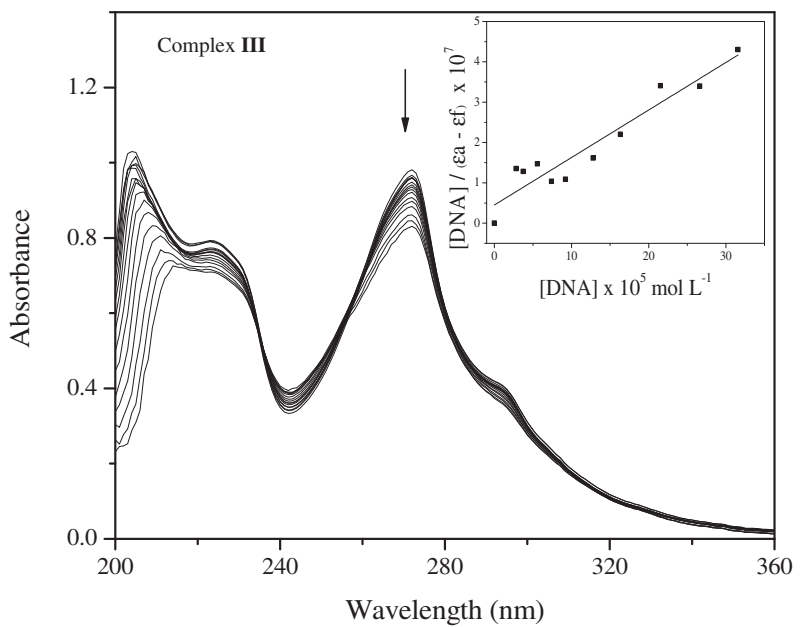

Fig. 7. Spectra of solutions containing complex III $\left(2.5 \times 10^{-5} \mathrm{M}\right)$ and increasing concentrations of DNA in HEPES buffer $\mathrm{pH}$ 7.3. [DNA]: [complex III] ranging from 0 to 12. Inset: $[\mathrm{DNA}] /(\varepsilon \mathrm{a}-\varepsilon \mathrm{f})$ versus $[\mathrm{DNA}]$.

morphology caused by interactions with drugs or small molecules. The CD spectrum of the free DNA is composed of a positive band at $275 \mathrm{~nm}$, due to base stacking, and a negative one at $245 \mathrm{~nm}$, due to the right- handed helicity of B-DNA [55-56]. By adding aliquots of I and III in the DNA solution the intensity of DNA bands increase (Fig. S4). This behavior is usually observed upon drug intercalation, since it enhances the base stacking and stabilizes helicity, and thus increases intensities of the bands, whereas simple groove binding and electrostatic interaction of small molecules show less or no perturbation on the base stacking and helicity bands [55-56].

\subsection{Anti-M. tuberculosis activity}

The antimycobacterial activity of compounds I and III were evaluated in vitro against MTB H37Rv (ATCC 27294) strain by the REMA method. The minimum inhibitory concentrations (MICs) found for the complexes, free ligands and rifampicin (standard drug) are shown in Table 6 . The complexes I and III exhibited activity against the MTB with MIC values equal to 6.3 and $6.5 \mu \mathrm{g} / \mathrm{mL}$, respectively. It is worth noting that the novel complexes possess MIC $(\mu \mathrm{M})$ values lower than those of the corresponding free ligands. Moreover, compared to similar compounds containing aromatic diimine ligands $(\mathrm{N}-\mathrm{N})$ already described, they are among the most active [57-59]. Whereas compounds with anti-MTB activity at $\leq 10 \mu \mathrm{g} / \mathrm{mL}$ (or molar equivalent) are selected for subsequent tests [60], these results show that copper complexes containing hydrazides and $\mathrm{N}, \mathrm{N}$-donor ligands are promising agents against MTB.

\section{Concluding remarks}

Five new copper complexes containing hydrazides and $\mathrm{N}, \mathrm{N}$-donor heterocyclic ligands were prepared and characterized. The X-ray structural analysis of one representative compound indicates that the geometry around the copper ion is octahedral distorted, in which both the ligands are coordinated in a bidentate mode, $(\mathrm{N}-\mathrm{O})$ and $(\mathrm{N}-\mathrm{N})$. EPR parameters determined for the all series of complexes corroborated these data, attesting a tetragonal geometry around the copper ion in solution. The obtained results of cytotoxicity activity of the synthesized compounds are very promising, especially in the case of copper

Table 6

Anti-MTB activity (MIC) of I, III, free ligands and rifampicin.

\begin{tabular}{lll}
\hline Compound & $\begin{array}{l}\mathrm{MIC}_{90} \\
\mu \mathrm{g} / \mathrm{mL}\end{array}$ & $\begin{array}{l}\mathrm{MIC}_{90} \\
\mu \mathrm{M}\end{array}$ \\
\hline phen & 2.3 & 12.7 \\
$4-\mathrm{FH}$ & $>25$ & - \\
$4-\mathrm{NH}$ & $>25$ & - \\
{$\left[\mathrm{Cu}(4-\mathrm{FH})(\right.$ phen $\left.)\left(\mathrm{ClO}_{4}\right)_{2}\right]$ I } & 6.3 & 10.0 \\
{$\left[\mathrm{Cu}(4-\mathrm{NH})(\right.$ phen $\left.)\left(\mathrm{ClO}_{4}\right)_{2}\right] . \mathrm{H}_{2} \mathrm{O}$ III } & 6.5 & 10.1 \\
Rifampicin (standard drug) & 0.02 & 0.03 \\
\hline
\end{tabular}


complexes with phenanthroline, with $\mathrm{IC}_{50}$ values in the range of a few $\mu \mathrm{M}$. Also, the coordination to the metal ion ameliorates the ligand activity. Regarding its antitubercular activity, they are among the most active in comparison to similar compounds, with MIC $\leq 10 \mu \mathrm{g} / \mathrm{mL}$. These findings are noteworthy and motivate further studies with such compounds.

\section{Abbreviations}

\begin{tabular}{|c|c|}
\hline Phen & 1,10-phenanthroline \\
\hline bipy & $2,2^{\prime}$-bipyridine \\
\hline $\mathrm{dmb}$ & 4-4'-dimethoxy-2-2'-bipyridine \\
\hline DNA & Deoxyribonucleic acid \\
\hline CT DNA & calf-thymus DNA \\
\hline UV-Vis & ultraviolet-visible \\
\hline IR & infrared \\
\hline EPR & electron paramagnetic resonance \\
\hline $\mathrm{CD}$ & circular dichroism \\
\hline DMSO & dimethyl sulfoxide \\
\hline K562 & chronic myelogenous leukemia \\
\hline MCF-7 & breast adenocarcinoma \\
\hline \multicolumn{2}{|c|}{ MDA-MB-231 human breast adenocarcinoma } \\
\hline $\mathrm{IC}_{50}$ & concentration required to inhibit $50 \%$ of cell growth \\
\hline MIC & minimum inhibitory concentration \\
\hline MTB & Mycobacterium tuberculosis \\
\hline CT & charge transfer \\
\hline
\end{tabular}

\section{Acknowledgements}

To CNPq (Conselho Nacional de Desenvolvimento Científico e Tecnológico, Brazil) (442328/2014-1), CAPES (Coordenação de Aperfeiçoamento de Pessoal de Nível Superior, Brazil), and FAPEMIG (Fundação de Amparo à Pesquisa de Minas Gerais, Brazil) (APQ-0066815) by financial support and fellowships. The authors are also thankful to the Grupo de Materiais Inorgânicos do Triângulo - GMIT research group supported by FAPEMIG (APQ-00330-14). This work is a collaboration research project of members of the Rede Mineira de Química (RQ-MG) supported by FAPEMIG (Project: CEX - RED-00010-14).

\section{Appendix A. Supplementary data}

CCDC 1499893 contains the supplementary crystallographic data for the complex I. These data can be obtained free of charge via http:// www.ccdc.cam.ac.uk/conts/retrieving.html, or from the Cambridge Crystallographic Data Centre, 12 Union Road, Cambridge CB2 1EZ, UK; fax: (+ 44) 1223-336-033; or e-mail: deposit@ccdc.cam.ac.uk. Supplementary data associated with this article can be found in the online version, at http://dx.doi.org/10.1016/j.jinorgbio.2017.04.024.

\section{References}

[1] M. Chikira, C. Hee Ng, M. Palaniandavar, Int. J. Mol. Sci. 16 (2015) 22754-22780.

[2] P. Ruíz, R. Ortiz, L. Perelló, G. Alzuet, M. González-Álvarez, M. Liu-González, F. Sanz-Ruíz, J. Inorg. Biochem. 101 (2007) 831-840.

[3] P.R. Reddy, A. Shilpa, N. Raju, P. Raghavaiah, J. Inorg. Biochem. 105 (2011) 1603-1612.

[4] A.K. Patra, S. Roy, A.R. Chakravarty, Inorg. Chim. Acta 362 (2009) 1591-1599.

[5] I. Correia, S. Roy, C.P. Matos, S. Borovic, N. Butenko, I. Cavaco, F. Marques, J. Lorenzo, A. Rodríguez, V. Moreno, J.C. Pessoa, J. Inorg. Biochem. 147 (2015) $134-146$.

[6] A.M. Thomas, A.D. Naik, M. Nethaji, A.R. Chakravarty Inorg, Chim. Acta 357 (2004) 2315-2323.

[7] C. Marzano, M. Pellei, F. Tisato, C. Santini, Anti Cancer Agents Med. Chem. 9 (2009) 185-211.

[8] C. Santini, M. Pellei, V. Gandin, M. Porchia, F. Tisato, C. Marzano, Chem. Rev. 114 (2014) 815-862.

[9] J.L. García-Giménez, M. González-Álvarez, M. Liu-González, B. Macías, J. Borrás, G. Alzuet, J. Inorg. Biochem. 103 (2009) 923-934.

[10] T. Kiran, V.G. Prasanth, M.M. Balamurali, C.S. Vasavi, P. Munusami, K.L. Sathiyanarayanan, M. Pathak, Inorg. Chimica Acta 433 (2015) 26-34.
[11] T. Ma, J. Xu, Yuan Wang, H. Yu, Y. Yang, Y. Liu, W. Ding, W. Zhu, R. Chen, Z. Ge, Y. Tan, L. Jia, T. Zhu, J. Inorg. Biochem. 144 (2015) 38-46.

[12] P. Gurumoorthy, D. Mahendiran, D. Prabhu, C. Arulvasu, A.K. Rahiman, J. Mol. Struct. 1080 (2015) 88-98.

[13] S. Abdolmaleki, M. Ghadermazi, A. Fattahi, S. Sheshmani, Inorg. Chimica Acta 443 (2016) 284-298.

[14] I. Castillo, M. Suwalsky, M.J. Gallardo, V. Troncoso, B.N. Sánchez-Eguía, E. Santiago-Osorio, I. Aguiñiga, A.K. González-Ugarte, J. Inorg. Biochem. 156 (2016) 98-104.

[15] J. Serment-Guerrero, P. Cano-Sanchez, E. Reyes-Perez, F. Velazquez-Garcia, M. Bravo-Gomez, L. Ruiz-Azuara, Toxicol. in Vitro 25 (2011) 1376-1384.

[16] S. Iglesias, N. Alvarez, M.H. Torre, E. Kremer, J. Ellena, R.R. Ribeiro, R.P. Barroso, A.J. Costa-Filho, M.G. Kramer, G. Facchin, J. Inorg. Biochem. 139 (2014) 117-123.

[17] P.P. Silva, W. Guerra, J.N. Silveira, A.M. Da Costa Ferreira, T. Bortolotto, F.L. Fischer, H. Terenzi, A. Neves, E.C. Pereira-Maia, Inorg. Chem. 50 (2011) 6414-6424.

[18] T. Bortolotto, P.P. Silva, A. Neves, E.C. Pereira-Maia, H. Terenzi, Inorg. Chem. 50 (2011) 10519-10521.

[19] J.C. Almeida, D.A. Paixão, I.M. Marzano, J. Ellena, M. Pivatto, N.P. Lopes, A.M. Da Costa Ferreira, E.C. Pereira-Maia, S. Guilardi, W. Guerra, Polyhedron 89 (2015) 1-8.

[20] P.S. Lopes, D.A. Paixão, F.C.S. de Paula, A.M. Da Costa Ferreira, J. Ellena, S. Guilardi, E.C. Pereira-Maia, W. Guerra, J. Mol. Struct. 1034 (2013) 84-88.

[21] S. Rollas, Ş.G. Küçükgüzel, Molecules 12 (2007) 1910-1939.

[22] L.M. Sousa, P.P. Corbi, A.L.B. Formiga, Marcelo Lancellotti, I.M. Marzano, E.C. Pereira-Maia, G. Von Poelhsitz, W. Guerra, J. Mol. Struct. 1097 (2015) 15-22.

[23] M.A. Rodrigues, I.M. Marzano, G.H. Ribeiro, L. Colina-Vegas, M. Pivatto, A.P.S. Fontes, C.M. Ribeiro, F.R. Pavan, K.J. Almeida, A.A. Batista, E.C. PereiraMaia, W. Guerra, Polyhedron 98 (2015) 146-153.

[24] E.H.S. Sousa, F.G.M. Vieira, J.S. Butler, L.A. Basso, D.S. Santiago, I.C.N. Diógenes, L.G.F. Lopes, P.J. Sadler, J. Inorg. Biochem. 140 (2014) 236-244.

[25] E.H.S. Sousa, L.A. Basso, D.S. Santos, I.C.N. Diógenes, E. Longhinotti, L.G.F. Lopes, I.S. Moreira, J. Biol. Inorg. Chem. 17 (2012) 275-283.

[26] S.A. Galal, K.H. Hegab, A.S. Kassab, M.L. Rodriguez, S.M. Kerwin, A. Abdel-Mo'men, El-Khamry, H.I. El Diwani, Eur. J. Med. Chem. 44 (2009) 1500-1508.

[27] V. Mahalingam, N. Chitrapriya, M. Zeller, K. Natarajan, Polyhedron 28 (2009) 1532-1540.

[28] P. Sur, S.P. Chatterjee, P. Roy, B. Sur, Cancer Lett. 94 (1995) 27-32.

[29] G.D. de Souza, M. A, L.E. Fernandes, P.P. Silva, R. Ruggiero, E.C. Pereira-Maia, W. Guerra, Cent. Eur. J. Chem. 11 (2013) 290-294.

[30] N. Dodoff, K. Granharov, N. Spassovska, J. Inorg. Biochem. 60 (1995) 257-266.

[31] P.P. Silva, W. Guerra, G.C. dos Santos, N.G. Fernandes, J.N. Silveira, A.M. da Costa Ferreira, T. Bortolotto, H. Terenzi, A.J. Bortoluzzi, A. Neves, E.C. Pereira-Maia, J. Inorg. Biochem. 132 (2014) 67-76.

[32] T. Bortolotto, P.P. Silva-Caldeira, C.T. Pich, E.C. Pereira-Maia, H. Terenzi, Chem. Commun. 52 (2016) 7130-7133.

[33] G.M. Sheldrick, SHELXS97, Program for the Solution of Crystal Structures, University of Göttingen, Germany, 1997.

[34] G.M. Sheldrick, SHELXL2014.

[35] J.C. Palomino, A. Martin, M. Camacho, H. Guerra, J. Swings, F. Portaels, Antimicrob. Agents Chemother. 46 (2002) 2720-2722.

[36] K. Shin-Geol Kang, Ryu, Soo-Kyung Jung, Shang-Su Kim, Bull. Kor. Chem. Soc. 17 (1996) 331-334.

[37] S. Dey, T. Mukherjee, S. Sarkar, H.S. Evans, P. Chattopadhyay, Transit. Met. Chem. 36 (2011) 631-636.

[38] K. Kaabi, M. El Glaoui, M. Zeller, C.B. Nasr, Acta Cryst E66 (2010) m1145-m1146.

[39] T. Pivetta, F. Trudua, E. Valletta, F. Isaia, C. Castellano, F. Demartin, R. Tuveri, S. Vascellari, A. pani. J. Inorg. Biochem. 141 (2014) 103-113.

[40] X. Li, Z. Zhang, C. Wang, T. Zhang, K. He, F. Deng. J. Inorg. Biochem. 105 (2011) 23-30.

[41] G.A. Van Albada, I. Dominicus, I. Mutikainen, U. Turpeinen, J. Reedijk. Polyhedron 26 (2007) 3731-3736.

[42] M.C. Etter, J.C. MacDonald, J. Bernstein, Acta Cryst B46 (1990) 256-262.

[43] M. McCann, A.L.S. Santos, B.A. da Silva, M.T.V. Romanos, A.S. Pyrrho, M. Devereux, K. Kavanagh, I. Fichtner, A. Kellet, Toxicol. Res. 1 (2012) 47-54.

[44] C. Santini, M. Pellei, V. Gandin, M. Porchia, F. Tisato, C. Marzano, Chem. Rev. 114 (2014) 815-862.

[45] M. Bravo-Gomez, J.C. Garcia-Ramos, I. Gracia-Mora, L. Ruiz-Azuara, J. Inorg. Biochem. 103 (2009) 299-309.

[46] D. İnci, R. Aydın, Ö. Vatan, T. Sevgi, D. Yılmaz, Y. Zorlu, Y. Yerli, B. Çoșut, E. Demirkan, N. Çinkılıç, J. Biol. Inorg. Chem. 22 (2017) 61-85.

[47] A. Marín-Hernandez, I. Gracia-Mora, L. Ruiz-Ramírez, R. Moreno-Sanchez, Biochem. Pharmacol. 65 (2003) 1979-1989.

[48] R. Singh, R.N. Jadeja, M.C. Thounaojam, T. Patel, R.V. Devkar, D. Chakraborty, Inorg. Chem. Commun. 23 (2012) 78-84.

[49] S. Patitungkho, S. Adsule, P. Dandawate, S. Padhye, A. Ahmad, F.H. Sarkar, Bioorg. Med. Chem. Lett. 21 (2011) 1802-1806.

[50] K.M. Vyas, R.N. Jadeja, D. Patel, R.V. Devkar, V.K. Gupta, Polyhedron 80 (2014) 20-33.

[51] E.K. Efthimiadou, H. Thomadaki, Y. Sanakis, C.P. Raptopoulou, N. Katsaros, A. Scorilas, A. Karaliota, G. Psomas, J. Inorg. Biochem. 101 (2007) 64-73.

[52] C. Fernandes, A. Horn Jr., B.F. Lopes, E.S. Bull, N.F.B. Azeredo, M.M. Kanashiro, F.V. Borges, A.J. Bortoluzzi, B. Szpoganicz, A.B. Pires, R.W.A. Franco, J.C. de Almeida, L.L.F. Maciel, J.A.L.C. Resende, G. Schenk, J. Inorg. Biochem. 153 (2015) 68-87.

[53] K.G. Daniela, P. Gupta, R.H. Harbach, W.C. Guida, Q.P. Dou, Biochem. Pharmacol. 
67 (2004) 1139-1151.

[54] Xue-Quan Zhou, Y. Li, Dong-Yan Zhang, Y. Nie, Zong-Jin Li, W. Gu, X. Liu, JinLei Tian, Shi-Ping Yan, Eur. J. Med. Chem. 114 (2016) 244-256.

[55] Ferenc Zsila, Int. J. Biol. Macromol. 72 (2015) 1034-1040.

[56] M. Sinan, M. Panda, A. Ghosh, K. Dhara, P.E. Fanwick, D.J. Chattopadhyay, S. Goswami, J. Am. Chem. Soc. 130 (2008) 5185-5193.

[57] H.R. Dholariya, K.S. Patel, J.C. Patel, K.D. Pate, Spectrochim. Acta A Mol. Biomol. Spectrosc. 108 (2013) 319-328.
[58] A.E. Hoffman, M. DeStefano, C. Shoen, K. Gopinath, D.F. Warner, M. Cynamon, R.P. Doylea, Eur. J. Med. Chem. 70 (2013) 589-593.

[59] J.C. Almeida, I.M. Marzano, M. Pivatto, N.P. Lopes, A.M. Da Costa Ferreira, F.R. Pavan, I.C. Silva, E.C. Pereira-Maia, G. Von Poelhsitz, W. Guerra, Inorg. Chim. Acta 446 (2016) 87-92.

[60] F.R. Pavan, D.N. Sato, C. Q., F. Leite, An approach to the search for new drugs against tuberculosis, in: P.-J. Cardona (Ed.), Mycobacterium tuberculosis/book 2, Intech, 2011. 